\title{
Plant biometric characterization and leaf micromorphometry of Talinum triangulare (Jacq.) Willd cultivated under shade ${ }^{1}$
}

\author{
Ellen Carla Francisca Alexandre ${ }^{2}$, Leandro Spíndola Pereira ${ }^{2}$, Jose Weselli de Sá Andrade \\ Sebastião Carvalho Vasconcelos Filho ${ }^{2}$, Adriano Jakelaitis ${ }^{2}$
}

$10.1590 / 0034-737 X 201865010007$

\begin{abstract}
Talinum triangulare (Jacq.) Willd, known as Ceylon spinach, Surinam purslane, or waterleaf, is cultivated for medicinal and food purposes. Among environmental factors, light is an important regulator of primary production, contributing to plant growth. However, the success of each plant species depends on its morphoanatomical responses to light. The aim of this study was to determine whether T. triangulare leaf micromorphometry is affected when grown in full sun and under shade, and if so, which plant biometric variables are affected. T. triangulare cultivation was tested in beds arranged in blocks under shade levels of $0,18,30$, and 50\%. Each bed was considered a basic experimental unit, totaling four replications per treatment. Plant height, stem diameter, leaf area, leaf fresh weight, stem fresh weight, specific leaf area, leaf area ratio, abaxial epidermis, and mesophyll thickness were higher as shade levels increased. However, there was a decrease in the number of leaves, root to shoot ratio, stomatal density on abaxial and adaxial surfaces, and palisade parenchyma thickness. Nevertheless, root length, leaf and stem dry weights, leaf weight ratio, adaxial stomatal index, adaxial epidermis, and spongy parenchyma thickness remained constant. Plants responded differently to shade, with morphological and anatomical changes, suggesting a phenotypic plasticity and raising the possibility of being grown both in shaded environments and in full sunlight.
\end{abstract}

Keywords: growth; anatomy; plasticity; luminosity.

\section{RESUMO}

\section{Caracterização biométrica da planta e micromorfometria foliar de Talinum triangulare (Jacq.) Willd cultivada sob sombreamento}

Talinum triangulare (Jacq.) Willd, conhecida como espinafre do Ceilão, beldroega graúda e folha d'agua é cultivada com fins medicinais e alimentares. Entre os fatores ambientais, a luz é um importante regulador da produção primária, contribuindo para o crescimento das plantas. No entanto, o sucesso de cada espécie de planta depende das respostas morfoanatômicas à luz. O objetivo deste estudo foi determinar se a micromorfometria da folha de T. triangulare e qual das variáveis biométricas da planta são afetadas quando cultivada em pleno sol e sob sombreamento. O cultivo de $T$. triangulare foi testado em canteiros dispostos em blocos com níveis de sombreamento de $0,18,30$ e $50 \%$. Cada canteiro foi considerado uma unidade experimental básica, totalizando quatro repetições por tratamento. A altura da planta, o diâmetro do caule, a área foliar, a massa fresca da folha, a massa fresca do caule, a área foliar específica, a razão de área foliar, a espessura da epiderme abaxial e do mesofilo foram maiores à medida que aumentaram os níveis de sombreamento. No entanto, houve uma diminuição no número de folhas, relação raiz: parte aérea, densidade estomática das superfícies abaxial e adaxial e de espessura do parênquima paliçádico. O comprimento da raiz, as massas secas das folhas e do caule,

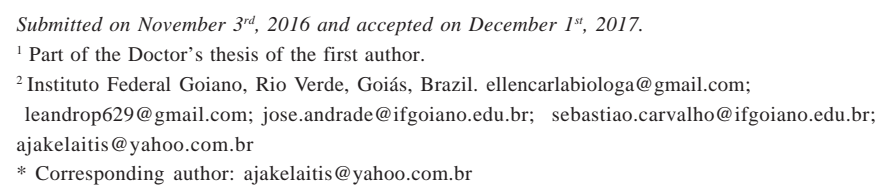


a razão de peso foliar, o índice estomático da face adaxial, a espessura da epiderme adaxial e do parênquima esponjoso, por sua vez, permaneceram constantes. As plantas responderam de forma diferente ao sombreamento, com mudanças morfológicas e anatômicas, sugerindo uma plasticidade fenotípica e aumentando a possibilidade de serem cultivadas tanto em ambientes sombreados quanto em pleno sol.

Palavras-chave: crescimento; anatomia; plasticidade; luminosidade.

\section{INTRODUCTION}

Talinum triangulare (Jacq.) Willd belongs to the family Talinaceae, previously Portulacaceae (Brilhaus et al., 2016). Its common names include Surinam purslane, Ceylon spinach, sweetheart, cariru, Florida spinach, potherb fame flower, lagos bologi, and waterleaf (Fasuyi, 2007; Aja et al., 2010; Liao et al., 2015). This species has pantropical distribution and adapts well to low fertility soils (Fasuyi, 2007; Nyffeler \& Eggli, 2010). Native to tropical Africa, it is cultivated for medicinal (Agbonon et al., 2010) and food purposes in South America, Asia, and Africa, especially in Nigeria (Ifon \& Bassir, 1979, 1980; Fasuyi, 2007).

In Brazil, leaves and stems of $T$. triangulare are sold as unconventional greens, mainly in the North, Northeast, and Midwest regions, by smallholders as a source of extra income (Brasileiro, 2010; Alexandre, 2016). Brazils' agricultural agency, Empresa Brasileira de Pesquisa Agropecuária (Embrapa), has conducted research on this species, to promote its use as an unconventional leafy vegetable (Brasil, 2010). The species has agronomic and economic potential, mainly by smallholders in need of alternative income sources.

Since climatic and genetic factors influence the performance of plants, it is necessary to conduct research with genotypes under various climatic conditions. Among physical environmental factors, light levels regulate the primary production and influence plant growth (Dalmolin et al., 2015). In this sense, shade screens have been used alone or in combination in protected environments, making the resulting microclimatic conditions appropriate for crop growth. Thus, the harmful effects of high incidence of solar radiation are reduced, also protecting against extreme temperatures (Morais et al., 2011).

It is crucial to understand the physiology of plant development, as well as the impacts of abiotic and biotic factors, so that management practices can be adopted to improve plant productivity (Goenaga, 1995). Several studies have reported the benefit of using shade for the cultivation of different plant species, such as leaf cactus (Queiroz et al., 2015), taro (Oliveira et al., 2011), rocket salad (Grangeiro et al., 2011), coriander (Grangeiro et al.,
2011), and watercress (Hirata \& Hirata, 2015), among others.

The intensity of photosynthetically active radiation plays an important role in plant acclimation to UV radiation. Morphological and physiological characteristics influenced by high irradiance are also affected by blue light (Hoffmann et al., 2015). In pepper plants, these authors found that a high amount of blue light triggers specific biochemical and physiological processes, resulting in better acclimation and recovery of plants from stress produced by UV radiation. Among cultivated species, the ability to use light for biological production is variable, and morphoanatomical responses are responsible for the success of each species (Aragão et al., 2014).

Plant biometrics and anatomical measurements help understand differences in growth of plants cultivated in different environments. Therefore, evaluating the productive and anatomical characteristics of $T$. triangulare grown under different shade levels and in full sun is extremely important when aiming to develop a base of reliable information to guide agronomic practices necessary for its economic exploitation. The purpose of this study was to determine whether $T$. triangulare leaf micromorphometry is affected when cultivated in different shade levels, and if so, which plant biometric variables are affected.

\section{MATERIAL AND METHODS}

The experiment was carried out from October 2014 to March 2015 in Rio Verde, Goiás, Brazil (geographical coordinates: $17^{\circ} 48^{\prime} 55^{\prime \prime} \mathrm{S}$ and 50 $56^{\prime} 28^{\prime \prime} \mathrm{W}$, altitude of 753 $\mathrm{m})$. According to the Köppen and Geiger classification, the local climate is tropical (Aw). Annual precipitation varies from 1500 to $1800 \mathrm{~mm}$ and occurs mainly from October to May, with the dry season from June to September. Average annual temperature ranges from 20 to $35^{\circ} \mathrm{C}$.

Seeds for seedling production were obtained from plants in Rio Verde, in an area of natural occurrence. A voucher herbarium specimen (HRV 468) was deposited with the herbarium of the Federal Institute of Goiás in Rio Verde. After collection, seeds were germinated and developed 
during 21 days in polypropylene trays containing commercial substrate, in which thinning was also carried out. Subsequently, seedlings were transplanted to beds.

The soil in the experimental area was classified as a clayey Oxisol with the following physicochemical characteristics, at a depth of $0-20 \mathrm{~cm}: \mathrm{pH}\left(\mathrm{CaCl}_{2}\right), 5.7 ; 0.13$, $4.07,1.21,0.01,2.89,5.43$, and $8.32 \mathrm{cmol}_{\mathrm{c}} \mathrm{dm}^{-3}$ of $\mathrm{K}^{+}, \mathrm{Ca}^{2+}$, $\mathrm{Mg}^{2+}, \mathrm{Al}, \mathrm{H}+\mathrm{Al}, \mathrm{SB}$, and CEC, respectively; 27.74, 0.36, 5.0, $5.75,18.55,44.56$, and $21.34 \mathrm{mg} \mathrm{dm}^{-3}$ of P, B, Na, Cu, Fe, Mn, and $\mathrm{Zn}$, respectively; $\mathrm{V} \%$ of $65.3 \%$, and particle sizes of 590,100 , and $310 \mathrm{~g} \mathrm{~kg}^{-1}$ of sand, silt, and clay, respectively.

The greenhouse used in the trial was built with an arched metal structure, with an ordinary ceiling height of $1.4 \mathrm{~m}$ and a high point of $3.0 \mathrm{~m}$, length of $30 \mathrm{~m}$, and width of $5.2 \mathrm{~m}$, in north-south direction. The tunnel had galvanized iron structure with top and side closure with black shade screens for each shaded environment, representing 18, 30, and $50 \%$ radiation attenuation and full sun $(100 \%$ of incident radiation). For each shaded environment, beds were made by using a rotary tiller, incorporating an organic compound at a dose of $1 \mathrm{~kg} \mathrm{~m}^{\prime 2}$. The beds had dimensions of $5 \times 1 \mathrm{~m}$ (length $\times$ width). The spacing used was $0.25 \mathrm{~m}$ between rows and $0.25 \mathrm{~m}$ between plants. Each bed was considered a basic experimental unit, with four replications per treatment.

No phytosanitary products were applied during plant cultivation and weed control was manual. After harvest, at 118 days after transplanting, plant height, stem diameter, number of leaves, leaf area, length and volume of root system, and fresh and dry weight of leaves, stems, and roots of T. triangulare were assessed as a function of treatments. To measure plant height and root length, a ruler was used and for stem diameter, a caliper. To obtain root volume, roots were washed in tap water over a sieve until the complete removal of soil residues. Subsequently, the root system volume was measured by displacement of the water column in a graduated cylinder. Fresh weights of leaves, stems, and roots were obtained by weighing on an analytical balance. To determine dry weight, these materials were placed in paper bags and kept in a convection oven at $65{ }^{\circ} \mathrm{C}$ until reaching constant weight, which was expressed in $\mathrm{g}$ per plant. Leaf area was determined in $\mathrm{cm}^{2}$ by integrating the digital image of leaves using the software ImageJ (Image Processing and Analysis in Java), version 1.47 .

The micromorphometric analyses of the leaves regarding stomatal density index of the adaxial and abaxial surfaces and thickness of the adaxial and abaxial epidermis and palisade and spongy parenchyma were performed with the ANATI QUANTI ${ }^{\circledR}$ software (Aguiar et al., 2007). To obtain the stomatal density and index, the epidermisimprinting technique with cyanoacrylate was used, as described by Alves et al. (2014).
The effects of different environments were assessed on the anatomical structure of $T$. triangulare leaves using staining with toluidine blue. Leaf tissue thickening was measured with $0.5 \mathrm{~cm}^{2}$ samples removed from the middle third of leaves of each plant from the experimental treatment (in full sun and 18, 30, and 50\% shade) using a disposable razor. These samples were then fixed in Karnovsky's solution (1965) for $24 \mathrm{~h}$, dehydrated in ascending ethanol series, and pre-infiltrated and infiltrated in historesin (Leica kit) according to manufacturer's recommendations.

Subsequently, the material was cut into $5 \mu \mathrm{m}$-thick sections with a rotary microtome (Ciencor Scientific Ltda, model 1508R). The sections were stained with toluidine blue at $0.05 \%$ in $0.1 \mathrm{M}$ phosphate buffer at $\mathrm{pH} 6.8$ (O'Brien et al., 1964) for structural and micromorphometric analysis. Subsequently, images were obtained using an Olympus microscope, model BX61, with camera DP-72, described, and quantitatively estimated by using the software ImageJ (Image Processing and Analysis in Java), version 1.47.

The results were subjected to analysis of variance and, when significant, a regression test at 5\% probability was carried out using the Sisvar ${ }^{\circledR}$ software.

\section{RESULTS AND DISCUSSION}

Depending on the environments to which plants of $T$. triangulare were exposed, a variation in growth pattern was observed in plant height, number of leaves, stem diameter, and leaf area (Figures 1A-D). T. triangulare showed an increasing linear behavior for plant height as shade intensity increased, with an increment of $0.31 \mathrm{~cm}$ for each unit increase of the shade level within the tested range (Figure 1A). The increase in heights represented $10.43,14.39$, and $37.74 \%$ for 18,30 , and $50 \%$ shade, respectively, as compared with the plan height grown in full sun (Figure 1A). These results are in line with those reported by Oliveira et al. (2009), who studied Artemisia vulgaris $\mathrm{L}$. under red and blue Chromatinet-colored shade (50\%) and full sun. They found that plants exposed to full sun presented lower height $(36.68 \mathrm{~cm})$ when compared with plants exposed to shade with blue $(122.12 \mathrm{~cm})$ and red $(125.87 \mathrm{~cm})$ screens, which did not differ from each other.

Conversely, the number of leaves linearly declined by 1.16 per unit of increase in shade levels, representing decreases of $5.9,14.48$, and $15.53 \%$ for 18,30 , and $50 \%$ shade, respectively, as compared with the number of leaves in plants grown in full sun (Figure 1B). For Curatella americana $\mathrm{L}$. under full sun or $76 \%$ red screen shade, the larger leaf area growth counterbalanced the number of leaves. At 240 days, plants in full sun had a higher number of leaves and lower leaf area compared with plants grown under shade (Dalmolin et al., 2015), in agreement with our results for both number of leaves and leaf area. 
For some species, stem diameter is a highly plastic trait, and this is desirable because it ensures a greater support to shoots (Lee et al., 1997). With increased shade, stem diameter linearly increased by $0.0369 \mathrm{~mm}$ per shade unit, representing gains of $7.12,6.22$, and $17.78 \%$ for plants under shade levels of 18,30 , and $50 \%$, respectively, compared with stem growth of plants in full sunlight (Figure 1C). Nevertheless, Meira et al. (2012) observed that environments with full light and 25, 50 , and $75 \%$ shade did not affect stem diameter of Melissa officinalis L., which presented values of $0.43,0.68,0.49$, and $0.69 \mathrm{~mm}$, respectively, not corroborating the behavior observed in this study.

Similarly, with increased shade, leaf area presented a linear increase of $70.84 \mathrm{~cm}^{2}$ per shade unit, representing increases of $37.60,30.42$, and $94.81 \%$ for 18,30 , and $50 \%$ shade, respectively, compared with the leaf area in plants grown in full sun (Figure 1D). According to Lambers et al. (2008), plants under environments with low irradiance invest a higher amount of photoassimilates and other resources, aiming to increase leaf area and decrease weight
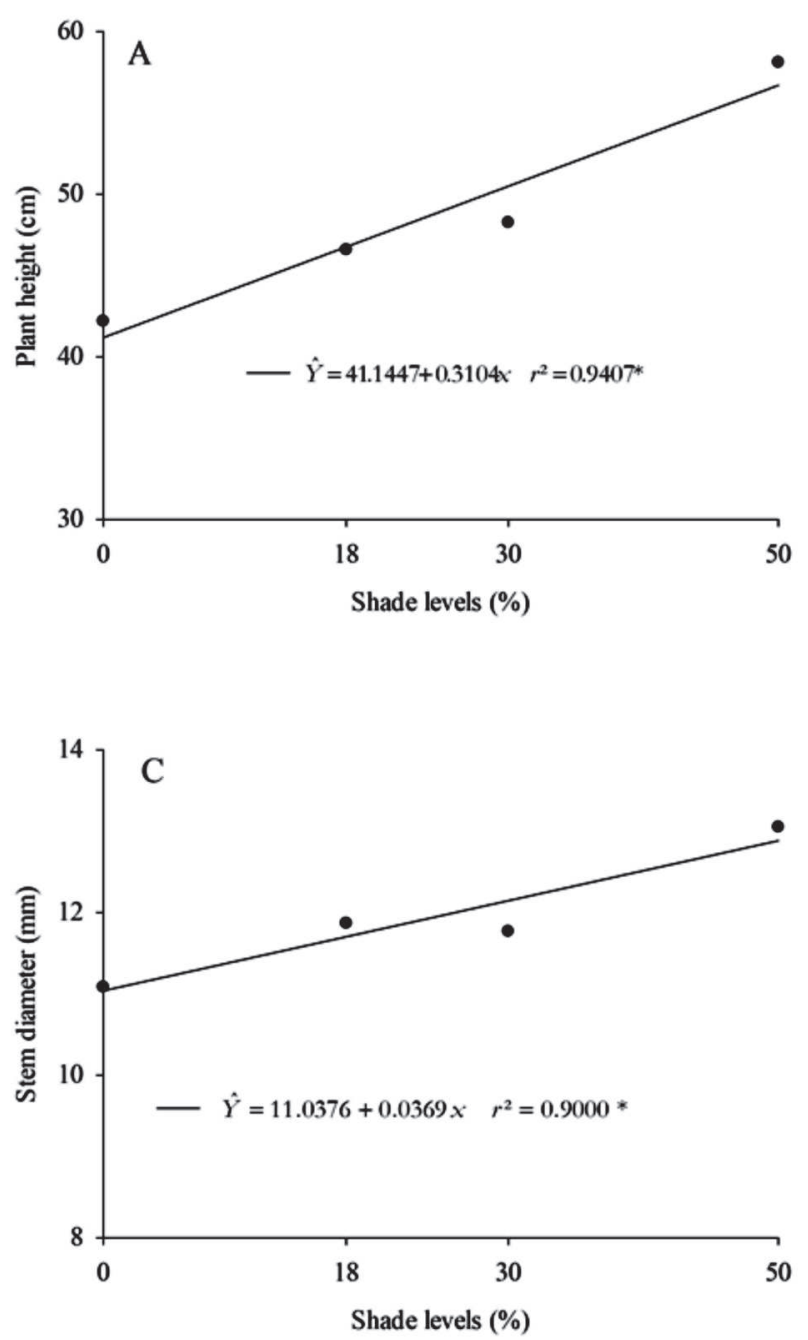

density to enlarge the capture of incident light and increase photosynthetic efficiency.

No significant effects were observed for root length of T. triangulare plants in function of the shade levels (Figure $2 \mathrm{~A}$ ). However, the variables root fresh weight, dry weight, and volume were affected with increased shade, having quadratic behavior with maximum points at 16.30 , 16.87 , and $11.19 \%$ shade, with values of $58.63 \mathrm{~g}, 9.62 \mathrm{~g}$, and $59.45 \mathrm{~mL}$ per plant, respectively (Figures 2B-D). In Aloysia gratissima (Gill et Hook) Tronc., a significant effect was observed in root dry matter of plants grown in full sun and shaded by 40 and $80 \%$ with Aluminet ${ }^{\circledR}$ screens, obtaining values of 32.8, 43.8, and 15.8 g, respectively (Pinto et al., 2007). According to Gonçalves et al. (2012), plants that grow in full sun present higher transpiration flows and require larger and more efficient root systems, with a better developed vascular system.

In relation to leaf and stem fresh weight, significant effects were observed, with linear increase in production with increasing shade levels (Figure 3A and B). For leaf
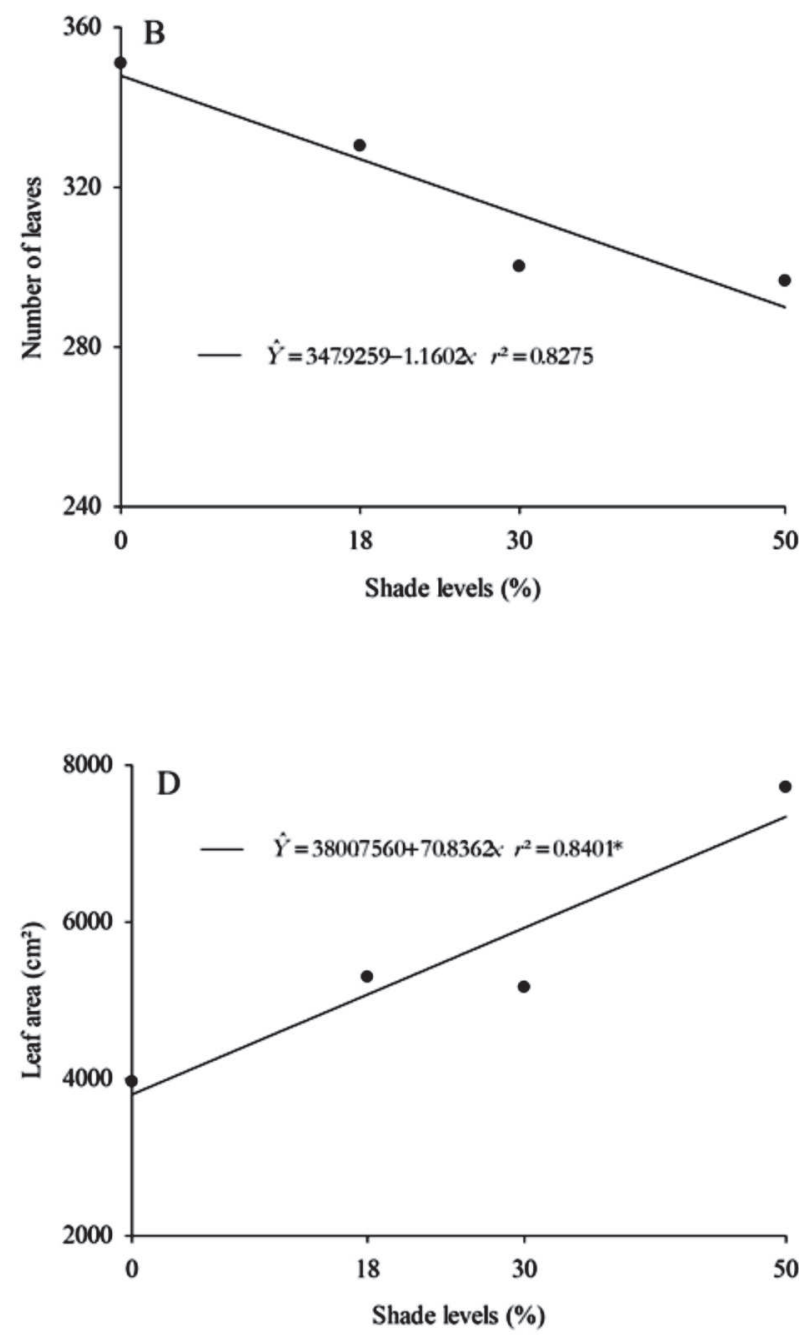

Figure 1: Plant height (A), number of leaves (B), stem diameter (C), and leaf area (D) of Talinum triangulare as a function of shade levels. 
fresh weight, the increment for each shade unit was 0.6165 g per plant, which represented increases of 20.79, 14.52, and $36.09 \%$ under 18,30 , and $50 \%$ shade, respectively, compared with plants grown in full sun. Similarly, for stem fresh weight, the increment for each shade unit was 0.889 g per plant, which represented increases of 13.11, 16.15, and $29 \%$ under 18, 30, and 50\% shade, respectively, compared with plants grown in full sun. However, no significant effects were observed for leaf and stem dry weight of $T$. triangulare plants in function of the shade levels (Figure 3C and D).

As shade levels increased, increases were observed in specific leaf area (Figure 4A) and leaf area ratio (Figure 4B). Leaf weight ratio of plants grown under shade did not change (Figure 4C), but their root-to-shoot ratio showed lower values (Figure 4D). For specific leaf area, increases of $11.64,40.56$, and $81.09 \%$ under 18,30 , and $50 \%$ shade, respectively, were observed compared with plants grown in full sun. Likewise, for specific leaf area, values represented gains of 11.39, 25.15, and 98.62\% under 18, 30, and $50 \%$ shade, respectively, compared with plants grown in full sun. Shaded plants usually present low leaf area
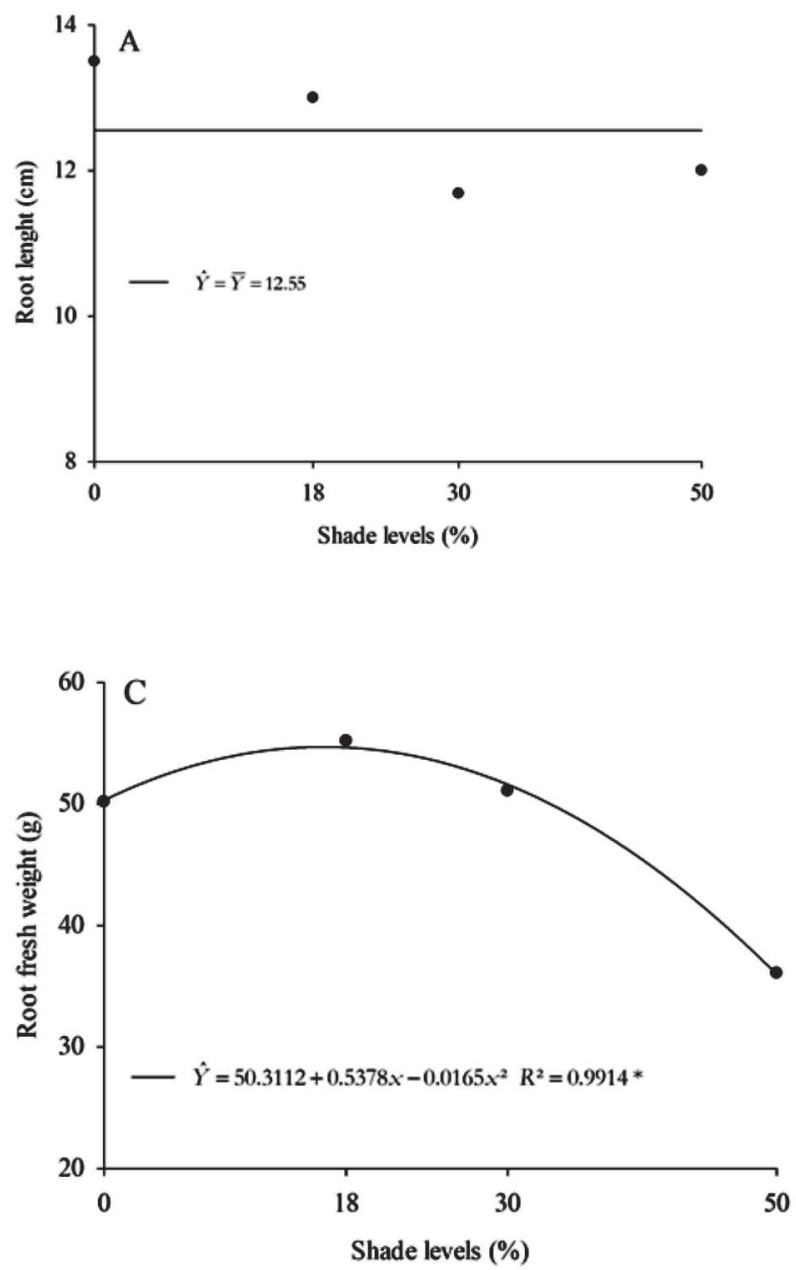

ratio in full sun because of their ability to adapt to different lighting conditions. In Mentha arvensis L. plants, Chagas et al., (2010) observed that shade levels (0, 30, 50, and $70 \%$ ) imposed by Aluminet ${ }^{\circledR}$ and black screens led to linear increases in specific leaf area, leaf area ratio, leaf weight ratio, and specific leaf weight. According to the authors, for every $10 \%$ increase in shade, increases of $0.219 \mathrm{dm}^{2} \mathrm{~g}^{-1}$, $0.087 \mathrm{dm}^{2} \mathrm{~g}^{-1}, 0.00747 \mathrm{~g} \mathrm{~g}^{-1}$, and $0.0497 \mathrm{~g} \mathrm{dm}^{-2}$, respectively, were estimated.

Linear decreases of $16.21,18.91$, and $54.05 \%$ were observed for root-to-shoot ratio of plants under 18, 30, and $50 \%$ shade, respectively, compared with plants grown in full sun. According to Oliveira et al. (2009), root-toshoot ratio can be changed by the interference of reallocating and distributing photoassimilates inside the plant due to environmental changes. In addition, plants of Artemisia vulgaris that were in full sun showed higher root-to-shoot ratio, suggesting priority allocation of dry weight to the root system as a consequence of light intensity.

Distribution of the dry weight of leaves, stems and roots of T. triangulare for 18,30 , and $50 \%$ shade levels
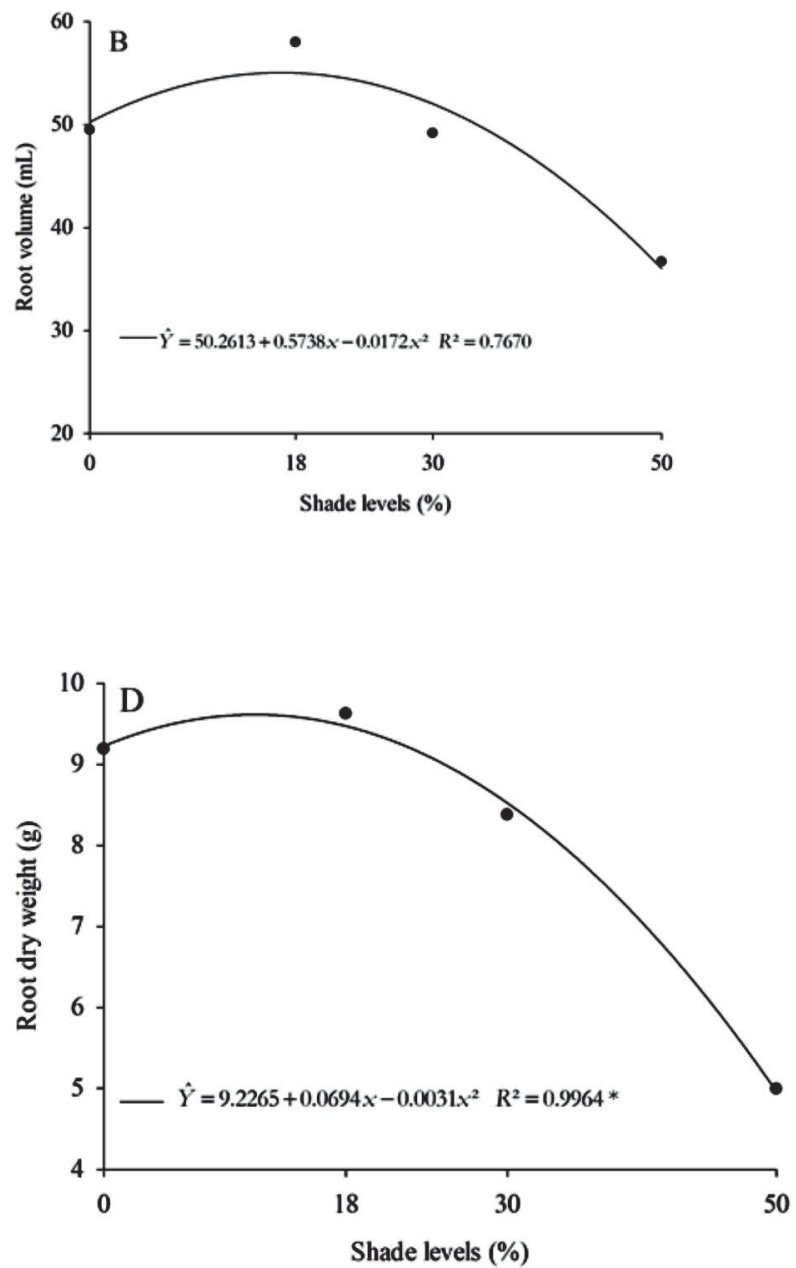

Figure 2: Root length (A), volume (B), fresh weight (C), and dry weight (D) of Talinum triangulare as a function of shade levels. 
were $23.15,55.55$, and $21.3 \%$, respectively (Figure 5). Plants grown under $50 \%$ shade showed the highest dry weight of leaves (24.4\%) and stems (61.1\%). Plants grown in full sun had the highest root dry weight (25.2\%).

Leaves of T. triangulare are amphistomatic. The stomatal index of abaxial surface epidermis showed decreasing behavior (Figure 6A) compared with the adaxial surface epidermis, whose stomatal index remained constant regardless of shade levels (Figure 6C). Stomatal index of abaxial surface reached the highest value (13.58\%) under $5.4 \%$ shade, and lower values were observed as shade levels increased, representing reductions of $0.22,4.80$, and $14.93 \%$ at levels of 18,30 , and $50 \%$, respectively (Figure $6 \mathrm{~A})$. There are specific advantages of using differentiated screens that influence the microclimate, changing the composition and intensity of the light that reaches plants, to optimize productivity. In addition, this light interferes with leaf anatomy at both the early and adult stages of development due to the plasticity of the leaf internal structures to adapt to ambient light (Oliveira et al., 2009).
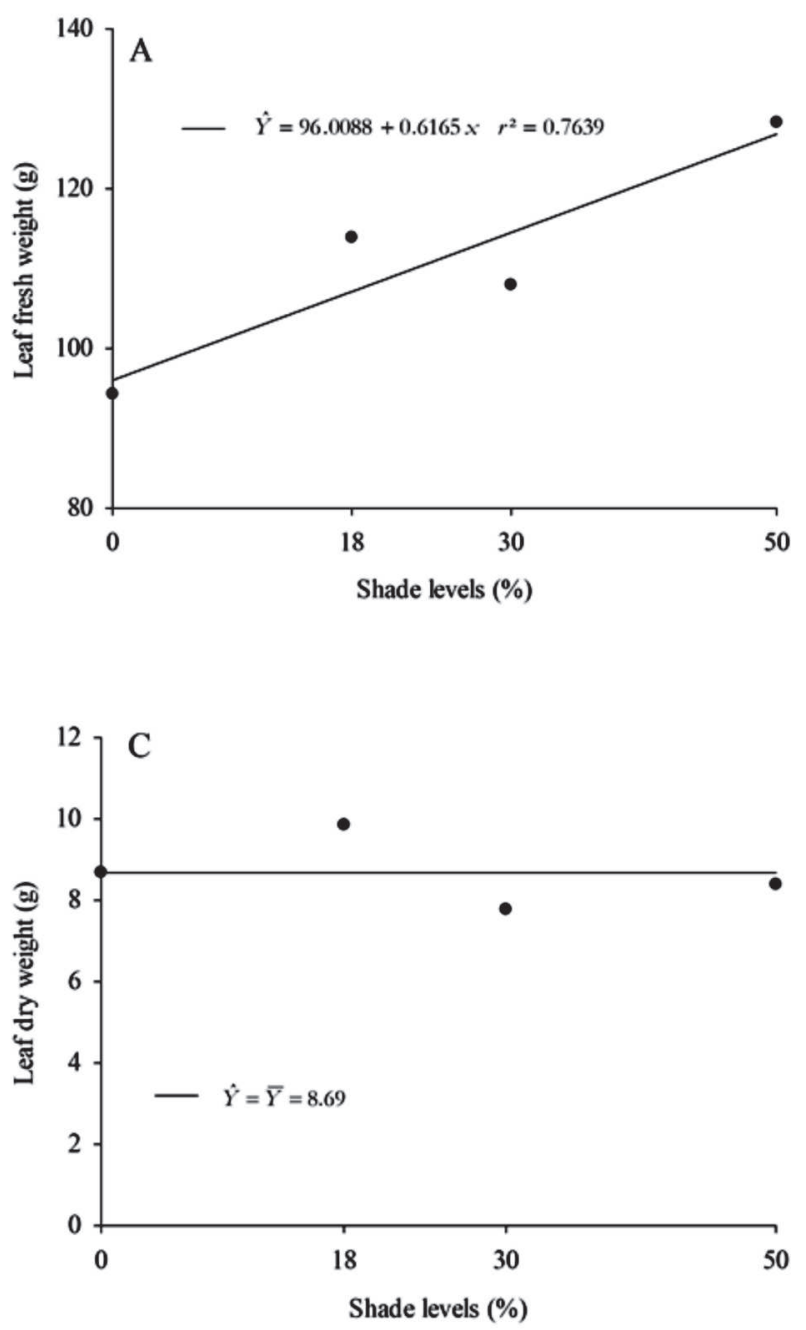

In environments where plants were exposed to higher radiation intensities, greater stomatal density was observed, especially on the abaxial epidermis (Figure 6B), which presented values more than twice the stomatal density on the adaxial surface (Figure 6D). For both epidermises, a linear decrease in the stomatal density was observed as shade levels increased. On the abaxial epidermis, this reduction was more significant, with a value of 1.16 stomata per $\mathrm{mm}^{2}$ of leaf, whereas on the adaxial surface this reduction was 0.2017 stomata per $\mathrm{mm}^{2}$ of leaf for each increase in shade unit (Figures 6C and 6D).

The increase of stomatal presence in leaves exposed to high irradiance may be an important adaptation mechanism of species that tolerate arid environments. In Curatella americana, plants under shade showed amphihypostomatic characteristics, with a reduction in stomatal density on the adaxial epidermis of leaves. These characteristics are observed in plants growing in mesophytic environments, evidencing leaf plasticity (Dalmolin et al., 2015).
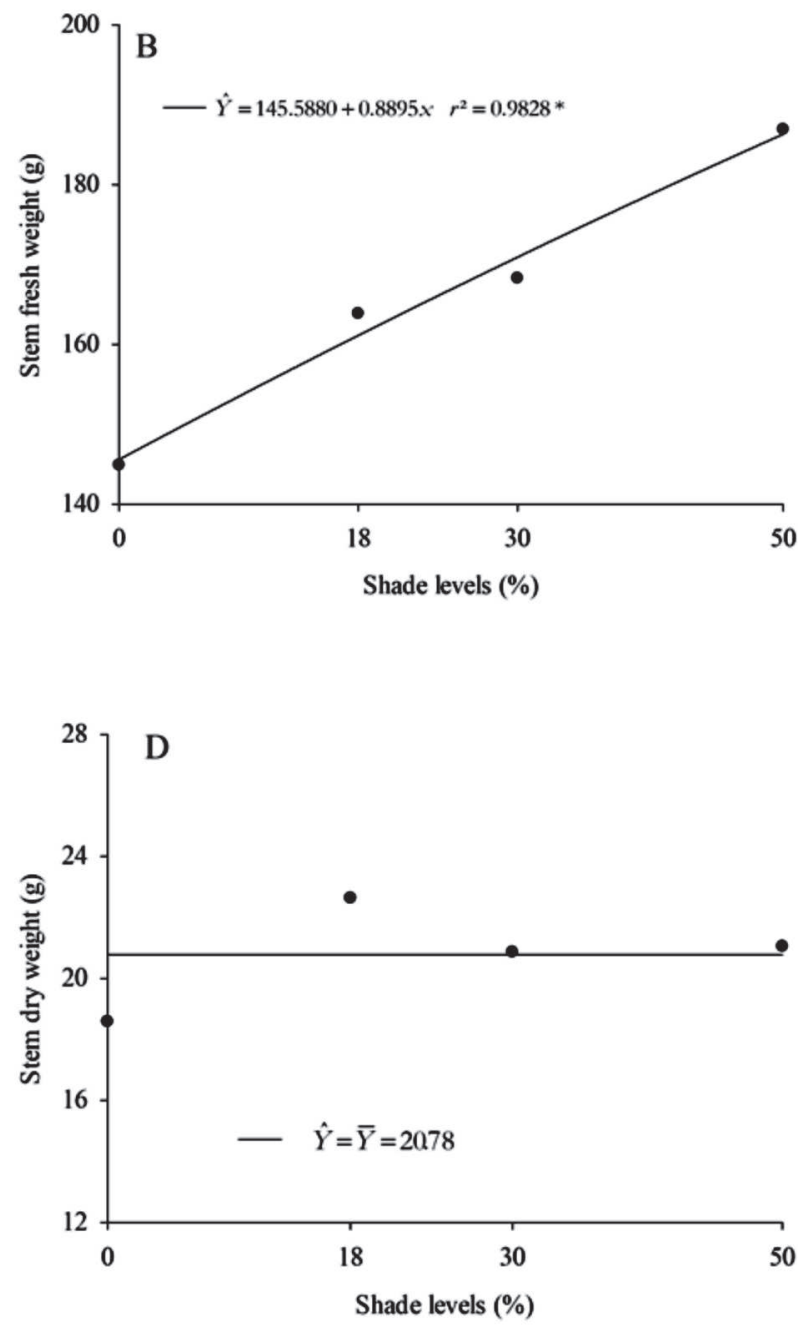

Figure 3: Leaf fresh weight (A), stem fresh weight (B), leaf dry weight (C), and stem dry weight (D) of Talinum triangulare as a function of shade levels. 
The abaxial epidermis thickness (Figure 7) of the plants was influenced by shade, showing an increasing linear behavior with an increment of $0.196 \mu \mathrm{m}$ per shade unit (Figure 7A) and an increase of 55.9\% for this variable in plants grown under $50 \%$ shade compared with plants grown in full sun. In contrast, shade levels did not affect either the thickness of the adaxial epidermis (Figure 7B) or the spongy parenchyma thickness (Figure 7C). Full sun, as well as 40 and $80 \%$ shade levels, significantly influenced the spongy parenchyma of Aloysia gratissima, which presented values of 59.1, 50.7, and $44.9 \mu \mathrm{m}$, respectively (Pinto et al., 2007).

In leaves of Aloysia gratissima, Pinto et al. (2007) observed that the abaxial epidermis thickness was influenced by environments, with values of $9.5 \mu \mathrm{m}$ for full sun, $8.1 \mu \mathrm{m}$ for $40 \%$ shade, and $11.2 \mu \mathrm{m}$ for $80 \%$ shade. According to the authors, those effects were also significant on the thickness of the adaxial surface epidermis of leaves, being higher in plants cultivated in full sun (40.3 $\mu \mathrm{m})$ compared with $40 \%(34.8 \mu \mathrm{m})$ and $80 \%(31.1 \mu \mathrm{m})$ shade.
Palisade parenchyma thickness was influenced by treatments: higher thickness values were observed when T. triangulare was grown in full sun and decreased linearly as shade levels increased (Figure 7D). According to Lambers et al. (2008), spongy parenchyma thickness is identical when leaves from shade and full sun are compared, whereas palisade parenchyma thickness is commonly lower in leaves under shade, which was also observed for T. triangulare. Pinto et al. (2007) also observed significantly lower palisade parenchyma thickness of plants grown in full sun and under 40 and $80 \%$ shade, with values of $154.4,102.9$, and $75.7 \mu \mathrm{m}$, respectively. Likewise, in plants of peanut forage grown in full sun and 50 and $80 \%$ shade, the palisade parenchyma thickness decreased linearly in order of 82.6, 73.9, and 65.6 $\mu \mathrm{m}$, respectively (Gobbi et al., 2011). In Artemisia vulgaris grown in full sun, a thicker palisade parenchyma (62.70 $\mu \mathrm{m})$ was observed compared with plants under red (54.15 $\mu \mathrm{m})$ and blue $(54.57 \mu \mathrm{m})$ Chromatinet-colored shade screens (50\%) (Oliveira et al., 2009).
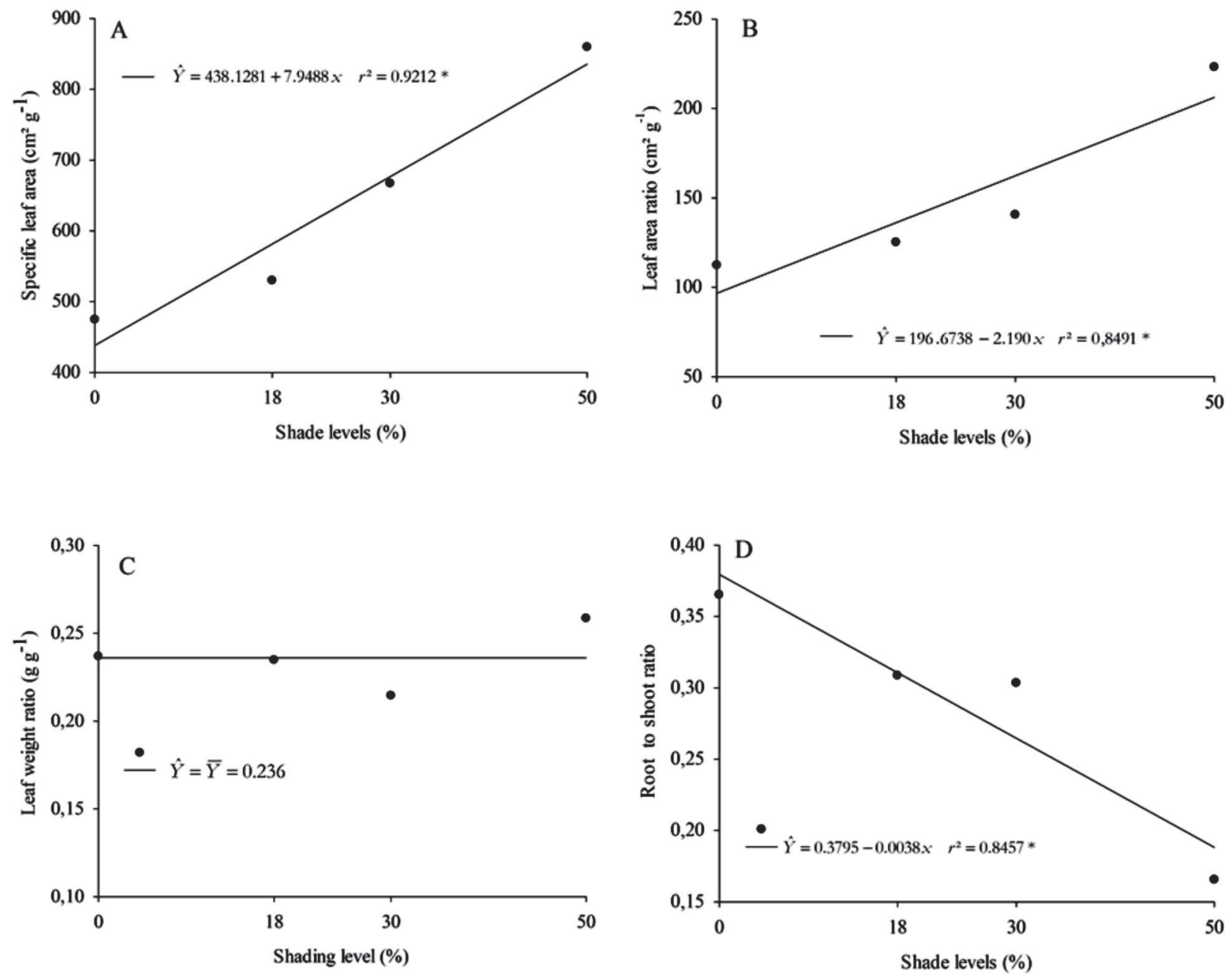

Figure 4: Specific leaf area (A), leaf area ratio (B), leaf weight ratio (C), and root to shoot ratio (D) of Talinum triangulare as a function of shade levels.

Rev. Ceres, Viçosa, v. 65, n.1, p. 044-055, jan/fev, 2018 


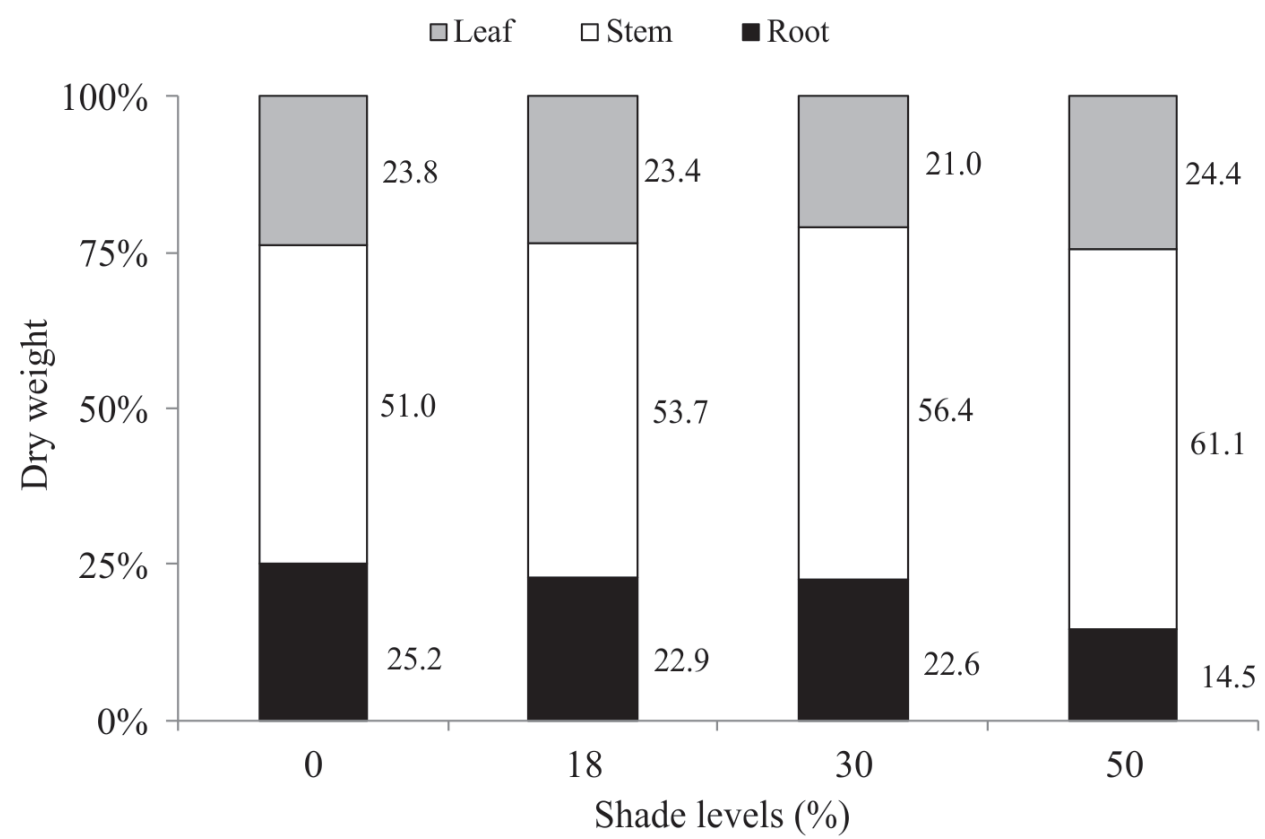

Figure 5: Dry weight distribution of leaves, stems, and roots of Talinum triangulare as a function of shade levels.
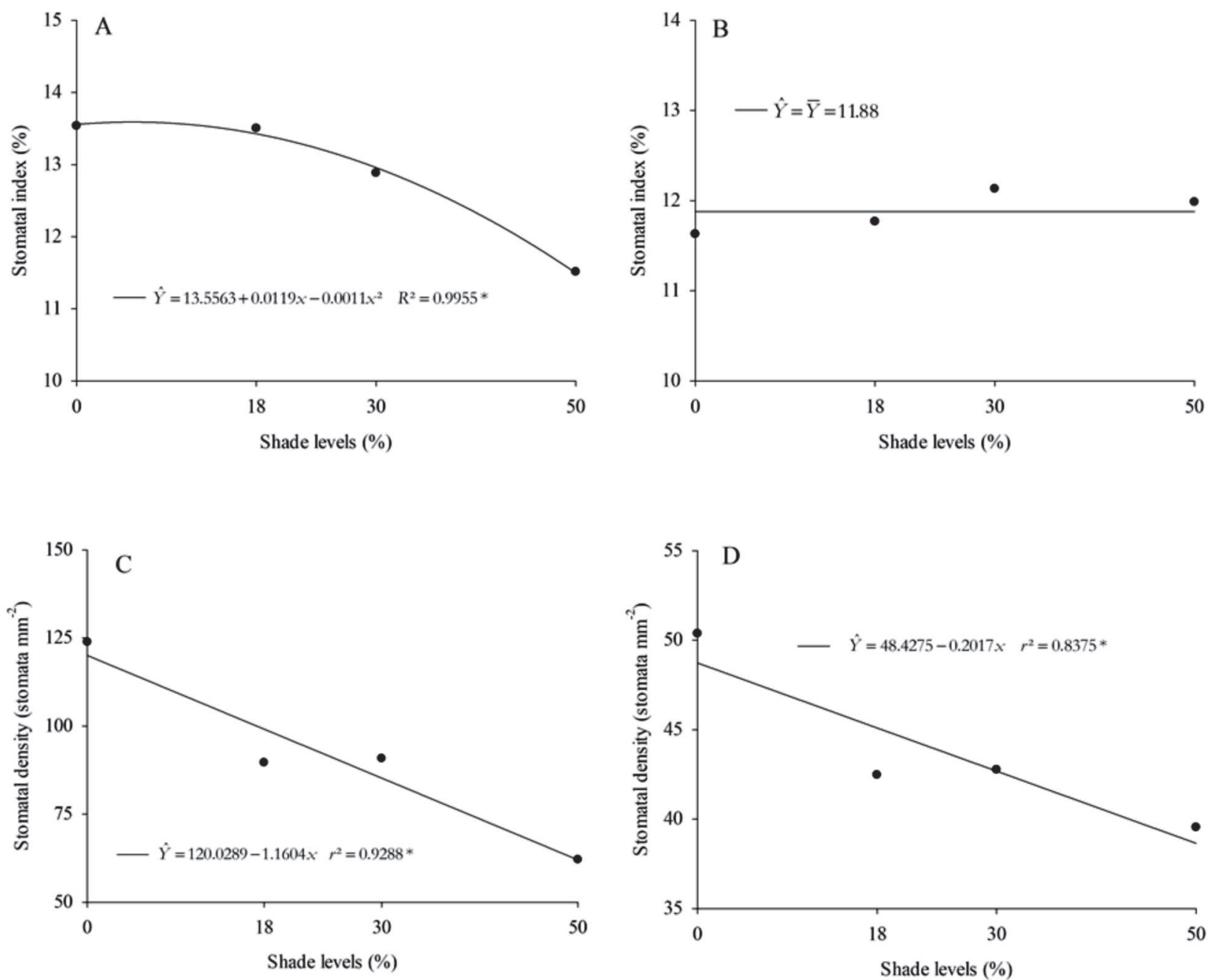

Figure 6: Abaxial surface stomatal index (A) and stomatal density (B) and adaxial surface stomatal index (C) and stomatal density (D) of Talinum triangulare leaves as a function of shade levels. 
Mesophyll thickness was reduced with increasing shade levels, showing quadratic behavior with a minimum point at $34.66 \%$ shade with value of $500.83 \mu \mathrm{m}$ (Figure 7E). Structural modifications found among leaves subjected to different radiation levels can be attributed to concentrations of distinct phytohormones, particularly auxin. Auxin enables greater distension of epidermal cells in leaves of shaded plants since it is concentrated in less illuminated regions of leaves. In contrast, more illuminated leaves
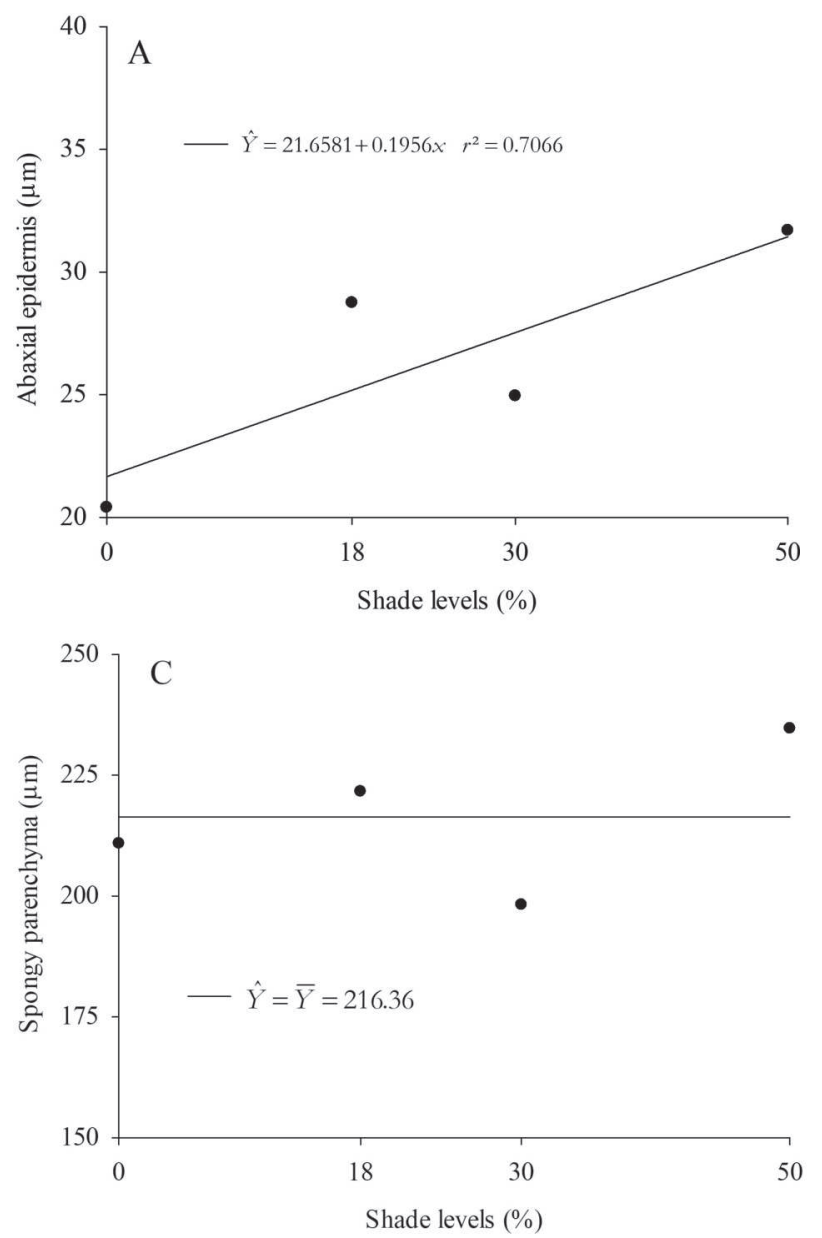

present higher levels of auxin in the mesophyll. In shaded leaves, auxin is located in the entire leaf, even the epidermis (Morais et al., 2004).

The presence of reduced number of stomata and other cells, but larger in size, for all shade levels characterized in the epidermal imprinting (Figure 8) was observed on the leaf adaxial surface. On the other hand, on the abaxial surface, an increased number of stomata and other cells, but smaller in size (Figure 8), was observed.
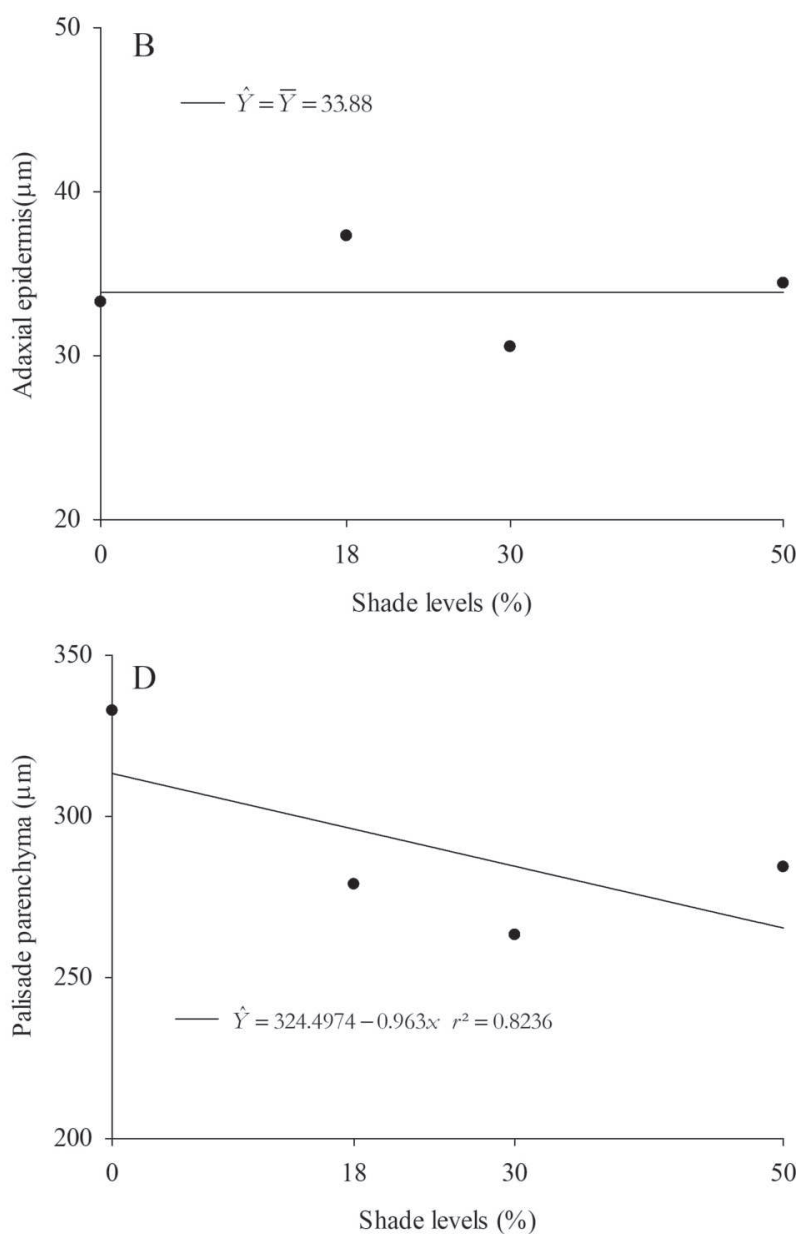

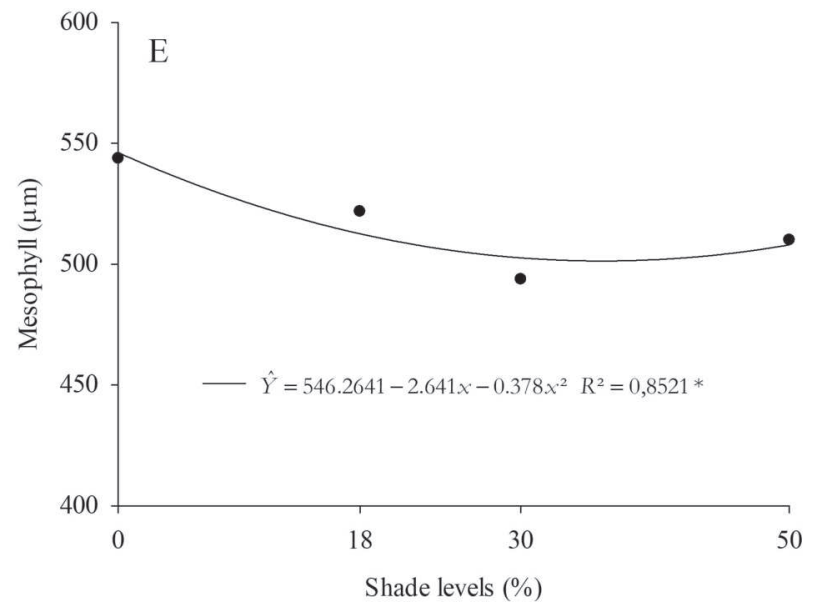

Figure 7: Talinum triangulare abaxial leaf (A) and adaxial leaf (B), epidermis spongy parenchyma (C), palisade parenchyma (D), and mesophyll thickness (E) as a function of shade levels. 


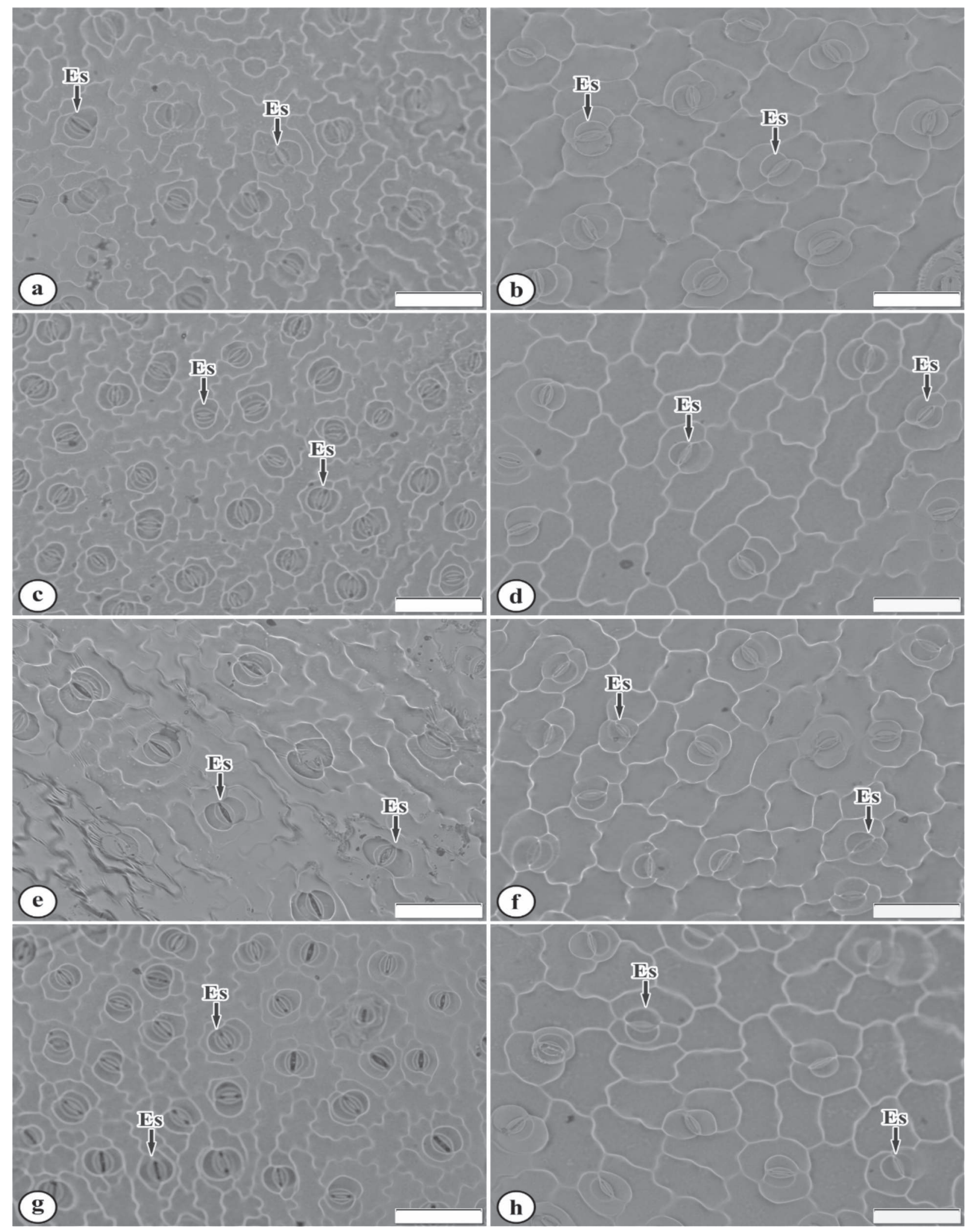

\section{Es $=$ Stomata.}

A-B: $18 \%$ shade; C-D: $30 \%$ shade; E-F: $50 \%$ shade; and G-H: full sunlight.

Photos on the left correspond to the abaxial surface and photos on the right correspond to the adaxial surface.

Bars: $100 \mu \mathrm{m}$.

Figure 8: Epidermal imprinting of both leaf surfaces of plants of Talinum triangulare (Jacq.) Willd as a function of different shade levels. 


\section{CONCLUSIONS}

Increasing shade levels increased height, stem diameter, leaf area, leaf and stem fresh weight, specific leaf area, leaf area ratio, and abaxial epidermis thickness.

Increasing shade levels decreased the number of leaves, root-to-shoot ratio, stomatal density of abaxial and adaxial epidermis, palisade parenchyma thickness, and mesophyll thickness.

Root length, leaf and stem dry weight, leaf weight ratio, stomatal index of the adaxial surface, adaxial epidermis thickness, and spongy parenchyma thickness of plants remained constant in full sun and 18, 30, and 50\% shade levels. T. triangulare plants subjected to full sun and 18 , 30 , and $50 \%$ shade levels responded differently, showing morphological and anatomical changes, suggesting phenotypic plasticity and the possibility of being grown both in shaded environments and in full sun.

\section{REFERENCES}

Agbonon A, Eklu-Gadegbekub K, Aklikokoub K, Gbeassorb M, Akpaganab K, Tamc TW, Arnasona JT \& Foster BC (2010) In vitro inhibitory effect of West African medicinal and food plants on human cytochrome P450 3A subfamily. Journal of Ethnopharmacology, 128:390-394.

Aguiar TV, Sant'anna-Santos BF, Azevedo AA \& Ferreira RS (2007) ANATI QUANTI: software de análises quantitativas para estudos em anatomia vegetal. Planta Daninha, 25:649-659.

Aja PM, Okaka ANC, Onu PN, Ibiam U \& Urako AJ (2010) Phytochemical composition of Talinum triangulare (water leaf) leaves. Pakistan Journal of Nutrition, 9:527-530.

Alexandre ECF (2016) Desempenho de Talinum triangulare (Jacq.) Willd cultivada sob sombreamento. Tese de Doutorado. Instituto Federal de Educação, Ciência e Tecnologia Goiano, Rio Verde. $76 \mathrm{p}$.

Alves RM, Inacio EM, Monquero PA, Meneghin SP \& Hirata A (2014) Leaf-surface characterization and the effects of the herbicide saflufenacil on the leaves of weeds. Revista Brasileira de Ciências Agrárias, 9:550-555.

Aragão DS, Lunz AMP, Oliveira LC, Raposo A \& Firmino Junior PCP (2014) Efeito do sombreamento na anatomia foliar de plantas jovens de andiroba (Carapa guianensis Aubl.). Revista Árvore, 38:631-639.

Brasil (2010) Ministério da Agricultura, Pecuária e Abastecimento. Manual de hortaliças não-convencionais. Brasília, Mapa/ ACS. 92p.

Brasileiro BG (2010) Germinação e produção de compostos fenólicos em plantas de Talinum triangulare (Jacq.) Wild (Portulacaeae) tratadas com homeopatia. Tese de Doutorado. Universidade Federal de Viçosa, Viçosa. 123p.

Brilhaus D, Bräutigam A, Mettler-Altmann T, Winter K \& Weber APM (2016) Reversible burst of transcriptional changes during induction of Crassulacean Acid Metabolism in Talinum triangulare. Plant Physiology, 170:102-122.

Chagas JH, Ribeiro AS, Pinto JEBP, Bertolucci SKV, Botrel PP \& Costa AG (2010) Análises foliares em plantas de Mentha arvensis cultivada sob diferentes malhas e níveis de sombreamento. Horticultura Brasileira, 28:3464-3471.
Dalmolin AC, Thomas SEO, Almeida BC \& Ortiz CER (2015) Alterações morfofisiológicas de plantas jovens de Curatella americana L. submetidas ao sombreamento. Revista Brasileira de Biociências, 13:41-48.

Fasuyi AO (2007) Bio-nutritional evaluations of three tropical leaf vegetables (Telfairia occidentalis, Amaranthus cruentus and Talinum triangulare as sole dietary protein sources in rat assay. Food Chemistry, 103:757-765.

Gobbi KF, Garcia R, Ventrella MC, Fróes A, Neto G \& Rocha GC (2011) Área foliar específica e anatomia foliar quantitativa do capim-braquiária e do amendoim-forrageiro submetidos a sombreamento. Revista Brasileira de Zootecnia, 40:1436-1444.

Goenaga R (1995) Accumulation and partitioning of dry matter in taro [Colocasia esculenta (L.) Schott]. Annals of Botany, 76:337-341

Gonçalves JFC, Melo GEF, Silva CEM, Ferreira MJ \& Justino JC (2012) Estratégias no uso da energia luminosa por plantas jovens de Genipa spruceana Steyerm ao alagamento. Acta Botanica Brasílica, 26:391-398.

Grangeiro LC, Freitas FCL, Negreiros MZ, Marrocos TPS, Lucena RRM \& Oliveira RA (2011) Crescimento e acúmulo de nutrientes em coentro e rúcula. Brazilian Journal of Agricultural Sciences, 6:11-16.

Hirata ACS \& Hirata EK (2015) Desempenho produtivo do agrião d'água cultivado em solo sob telas de sombreamento. Pesquisa Agropecuária Brasileira, 50:895-901.

Hoffmann AM, Noga G \& Hunsche M (2015) High blue light improves acclimation and photosynthetic recovery of pepper plants exposed to UV stress. Environmental and Experimental Botany, 109:254-263.

Ifon ET \& Bassir O (1979) The nutritive value of some Nigerian leafy green vegetables - Part 1: Vitamin and mineral contents. Food Chemistry, 4:263-267.

Ifon ET \& Bassir O (1980) The nutritive value of some Nigerian leafy green vegetables - Part 2: The distribution of protein, carbohydrates (including ethanol-soluble simple sugars), crude fat, fibre and ash. Food Chemistry, 5:231-235.

Karnovsky MJ (1965) A formaldehyde-glutaraldehyde fixative of high osmolarity for use in electron microscopy. Journal of Cell Biology, 27:137-138.

Lambers H, Chapin FS \& Pons TL (2008) Plant Physiological Ecology. New York, Springer. 540p.

Lee DW, Oberbauer SF, Krishnapilay B, Mansor M, Mohamad H \& Yap SK (1997) Effects of irradiance and spectral quality on seedling development of two Southeast Asian Hopea species. Oecologia, 110:01-09.

Liao DY, Chai YC, Wang SH, Chen CW \& Tsai MS (2015) Antioxidant activities and contents of flavonoids and phenolic acids of Talinum triangulare extracts and their immunomodulatory effects. Journal of Food and Drug Analysis, 23:294-302.

Meira MR, Martins ER \& Manganotti SA (2012) Crescimento, produção de fitomassa e teor de óleo essencial de melissa (Melissa officinalis) sob diferentes níveis de sombreamento. Revista Brasileira de Plantas Medicinais, 14:352-357.

Morais H, Medri ME, Marur CJ, Caramori PH, Ribeiro AMA \& Gomes JC (2004) Modifications on leaf anatomy of Coffea arabica caused by shade of Pigeonpea (Cajanus cajan). Brazilian Archives of Biology and Technology, 47:863-871.

Morais PLD, Dias NS, Almeida MLB, Sarmento JDA \& Sousa Neto ON (2011) Qualidade pós-colheita da alface hidropônica em ambiente protegido sob malhas termorefletoras e negra. Revista Ceres, 58:638-644. 
Nyffeler R \& Eggli U (2010) Desintegrating Portulacaceae: a new familial classification of the suborder Portulacineae (Caryophyllales) based on molecular and morphological data. Taxon, 59:227-240.

O'brien TP, Feder N \& McCully ME (1964) Polychromatic staining of plant cell walls by toluidine blue O. Protoplasma, 59:368-373.

Oliveira FL, Araújo AP \& Guerra JGM (2011) Crescimento e acumulação de nutrientes em plantas de taro sob níveis de sombreamento artificial. Horticultura Brasileira, 29:292-298.

Oliveira MI, Castro EM, Costa LCB \& Oliveira C (2009) Características biométricas, anatômicas e fisiológicas de Artemisia vulgaris L. cultivada sob telas coloridas. Revista Brasileira de Plantas Medicinais, 11:56-62.
Pinto JEBP, Cardoso JCW, Castro EM, Bertolucci SKV, Melo LA \& Dousseau S (2007) Aspectos morfofisiológicos e conteúdo de óleo essencial de plantas de alfazema-do-Brasil em função de níveis de sombreamento. Horticultura Brasileira, 25:210-214.

Queiroz CRAA, Moraes CMS, Andrade RRA \& Pavani LC (2015) Crescimento inicial e composição química de Pereskia aculeata Miller cultivada em diferentes luminosidades. Revista Agrogeoambiental, 7:93-104. 